\title{
Peter, Potter, Rabbits, Robbers
}

\author{
Rose Lovell-Smith
}

Critical discourses about realism and fantasy in children's literature have in the past included discussion of the merits, and demerits, of these conventions as they differently engage child readers. Beatrix Potter's works, situated at an intersection of the two literary conventions, seem to me rather to invite a useful complication of the distinction commonly made between them. Potter is clearly a fantasist. Yet aspects of her work support a scholarly tendency to claim her for realism, and this is often done by connecting Potter's life and works. An early example of this tendency may be seen in Margaret Lane's The Tale of Beatrix Potter, where there is a reproduction of the elaborate, beautiful and strange picture from The Tailor of Gloucester of a capped and gowned lady mouse, with mirror, seated on a gorgeously embroidered waistcoat. The fantastic content of the picture goes quite undiscussed, but the caption, I assume quoting Potter's own words, reads: 'The pictures of the embroidered waistcoat ... were drawn from show-case specimens in the 'V. and A.' which are probably still there' (Lane 1962 facing p.160). Attention was thus deflected by this early biography away from Potter's imaginative fantasy and towards Potter's verifiable contact with solid objects preserved in a museum. ${ }^{1}$

Emphasis on Potter's realism is also produced when Potter's drawings and paintings, whether of landscapes, buildings and gardens, interiors, wild and pet animals, botanical specimens, or of life under the microscope, are reproduced alongside illustrations from her published fantasy works - especially when the latter are selected in order to show their partial derivation from the former. ${ }^{2}$ The effect is to anchor even Potter's most extraordinary - and extraordinarily imaginative - artwork in her observation of the real world. The frequently repeated claim that Potter's animal characters are always drawn with anatomical accuracy has a similar effect - and it is true that Potter's careful work on the verification of detail in depicting animals is on record. ${ }^{3}$ Yet the claim can hardly be upheld. In the Peter Rabbit series of four connected tales, my focus in this essay, Mrs Rabbit's comfortably rounded body, which appears to have both a bosom and a waist, looks quite unlike a rabbit's: however we may read this maternal body, animal anatomy is unlikely to be uppermost in our minds. ${ }^{4}$

The substantial biographical and pictorial documentation of Beatrix Potter additionally follows a strong trend towards seeing her life up to 1902 as apprenticeship. Thus the life comes to account for the works which become comprehensible, even predictable, by way of Potter's life story. This, too, I would argue, is a way of referring Potter's achievement to her real world experience. The many reproductions of the first versions of her story-letters to child friends, for example, are presented in ways which refer her works to her lived experience, rather than as ways of celebrating Potter the fantasist, Potter the informed reader and reteller of Joel Chandler Harris and other fantastic animal folk tales. Recently, in the feature film Miss Potter, connections were made to Potter's sexuality by way of the animation of her animal characters (presented by the film makers in what struck me as very late-twentieth-century terms) $\quad-$ these animations thus become another instance of a well-established tendency to ground Potter's creative fantasy in her (assumed emotional) real-world experience (see Chris Noonan Miss Potter 2006).

In this essay I join those who have turned Potter studies towards investigating the cultural and 
literary contexts within which she worked. Such studies have been shown to complicate our ideas about Potter as a realist and can open up useful new directions into her fantasy worlds. See, for example, a number of the essays in Beatrix Potter's Peter Rabbit: A Children's Classic at 100, ed. Margaret Mackey, including those by Lissa Paul, which connects the art of Millais and Potter, by June Cummins, a study of 'Progressive intertextual revision' between Christina Rossetti's Goblin Market and Beatrix Potter's Peter Rabbit, and by Scott Pollard and Kara Keeling, who discuss the theme of food in Peter Rabbit in the light of the eight rabbit recipes in the 1861 Beeton's Book of Household Management. Another discussion of Potter which is aware of cultural contexts and antecedent texts is John Goldthwaite's in his The Natural History of Make-Believe (1996). Goldthwaite remarks that 'little has been made of [Potter's] life in books when so much of it was spent in them' (1996, p.287) and argues that Potter's chosen literary form is an exploration of the fable, discussing her narratives at some length and showing their probable origins in borrowings from Joel Chandler Harris's tales of Uncle Remus (pp.304-17). ${ }^{5}$

My own enquiry draws on Potter's cultural as well as some literary contexts. In researching this paper I wanted first of all to test a suspicion I had that Peter Rabbit himself might have been - if Mr McGregor had ever succeeded in catching him - stolen property. I therefore investigated what might have been assumed in 1902 about the character called Mr McGregor, as well as what Potter's original readers probably knew, thought, or believed about rabbits and their ownership. This enquiry has clarified much for me about the peculiar pleasures and puzzles Potter puts before her reader by way of her fantasy of human/animal characters, and the many ways these may be understood by child and adult readers.
The characterisation and role of Mr McGregor are topics particularly worth addressing, given that my students today usually take for granted that $\mathrm{Mr}$ McGregor is an independent small businessman, what New Zealanders call a 'market gardener' - whereas my own understanding is that Potter's contemporaries would have recognised him to be employed at a substantial country house or mansion. In fact, $\mathrm{Mr}$ McGregor is an example of a familiar kind of servant, and subsequent literary character, called a 'Scotch gardener.' The expectation that a gardener would be Scottish was strong in 19th century England - especially in the case of a chief gardener, one who might well be a manager of many under-gardeners and gardeners' boys. Such 'Scotch gardeners' had already become common figures in eighteenthcentury England, and fiction followed fact: thus in Jane Austen's Persuasion, (1818) the gardener at Kellynch Hall is, naturally, called MacKenzie (Austen 1965, p.66). See also William Makepeace Thackeray's Vanity Fair, where Sir Pitt and Lady Crawley's two neglected daughters, 'the Scotch gardener having luckily a good wife and some good children, ... got a little wholesome society and instruction in his lodge' (1847-8) [1983, p.98). . The phenomenon was sufficiently remarked upon for J. Wighton, gardener to the Earl of Stafford at Cossey Hall, to explain the popular preference for Scottish gardeners in England, especially in management, in the May 1840 number of The Gardener's Magazine. That the expectation remained alive towards the end of the century, too, is indicated by the republication of Robert Louis Stevenson's essay, 'An Old Scotch Gardener,' in Memories and Portraits in 1887. Stevenson's piece, written in the person of a female employer, or perhaps employer's wife, opens in elegiac mood, questioning whether her particular Scotch gardener, an octogenarian, is not perhaps the last of his breed. Her gardener is otherwise represented as tyrannical and selfwilled, maintaining a control over the garden 
which its mere owner feels powerless to change:

the sway that he exercised over your feelings he extended to your garden, and, through the garden, to your diet. He would trim a hedge, throw away a favourite plant, or fill the most favoured and fertile section of the garden with a vegetable that none of us could eat, in supreme contempt for our opinion. If you asked him to send you in one of your own artichokes, 'THAT I WULL, MEM,' he would say, 'WITH PLEASURE, FOR IT IS MAIR BLESSED TO GIVE THAN TO RECEIVE. ${ }^{7}$

Stevenson's essay suggests that the Scotch gardener remained a familiar idea, even if he may also have been a disappearing phenomenon: it also implies some popular uncertainty around the question as to who really owns the garden of a Scotch gardener. Possibly, like the figure of the Scotch gardener himself, the jocular wonderment expressed by Stevenson's narrator was something of a popular cliché.

Stevenson's 'Scotch gardener' also had a great literary prototype. The late nineteenth-century British readers who delighted in Stevenson's early writings would undoubtedly have already known, or known about, Andrew Fairservice, a character in Walter Scott's Rob Roy (1817). Fairservice is in fact acknowledged at the outset of Stevenson's portrait of 'An Old Scotch Gardener'. As Scott's popularity had hardly dimmed through the century, and Rob Roy was a perpetual favourite among Scott's novels, most adult readers may be assumed to have known this character, either at first or second hand, in 1902 when Peter Rabbit first appeared on the market.

Andrew Fairservice's 'allegorical' name indicates that he is a comic type. In the later stages of Rob Roy Fairservice accompanies Frank Osbaldistone, the narrating protagonist, on his travels first to Glasgow and then up to the Highland line, acquiring on this journey the qualities of a picaresque hero's servant and comic sidekick - garrulous, cowardly, cheeky, lying, snobbish. But when he is first met with at work in the gardens of Osbaldistone Hall in Northumbria Fairservice displays rather different qualities. Readers will mainly notice the pride and interest he takes in the garden which is his domain, and the 'great complacency' (Scott 1998, p.117) with which he regards his own qualifications and achievements. Like Potter's McGregor, Andrew is industrious, working late in the evenings (p.116, p.194), and when he tells Frank that 'a kail-blaid, or a colliflour, glances sae glegly by moonlight, it's like a leddy in her diamonds' (p.197) his delight in gardening is both evident, and comic, though of the kind of comedy which might also touch a reader's heart. The honesty of this Scotch gardener towards his employers, however, despite his fervent protestant affiliations and pious habits, is of a nature which he prefers to define for himself. For instance, when he tells Frank that he has had 'a wee bit business o' my ain wi' Mattie Simpson, that wants a forpit or twa o' peers, that will never be missed in the Ha'-house' - but that he was interrupted 'at the thrangest o' our bargain' (p.192) by a travelling merchant, we understand that Andrew is selling the produce of his employer's garden in the local village for his own profit.

Moreover, after Andrew has joined Frank in his speedy and secret night departure for Glasgow, it is revealed that Andrew has stolen the horse he is riding, and that he has in the past been a smuggler, an occupation he justifies as ' a mere spoiling of the Egyptians' (p.231) - adding 'puir auld Scotland suffers eneugh by thae blackguard loons o' excisemen and gaugers, that hae come down on her like locusts since the sad and sorrowfu' Union' (p. 231). This very political self-justification allies Andrew and his minor dishonesties with the larger politically and personally motivated acts of 
despoliation and robbery which are a major theme of the book throughout - central to the career of Rob Roy himself, and explored through the varied activities of many other characters. In fact, with regard to almost every character in Rob Roy it is difficult to draw the line between honesty and dishonesty, for cattlestealing, protection rackets or blackmail, and outright theft are differently perceived by different characters depending on their political sympathies. Andrew's minor depredations in the Osbaldistones' garden are therefore minor variations on a major motif in Rob Roy, and endow his characterisation with much more importance than that of incidental comic relief. Am I over-reading the Peter Rabbit series in noting that the most creative and efficient of all the many thieves in Scott's novel, Rob Roy himself, is also a MacGregor, in fact, 'the' MacGregor, a clan leader? This reading possibility is closely related to my first reason for beginning this enquiry, my question whether, in keeping a rabbit caught in his employers' garden, $\mathrm{Mr}$ McGregor has not himself become a robber. ${ }^{8}$

That question has, however, so far proven difficult for me to answer with total confidence, because Victorian ideas and practices with regard to wild, or wildish, rabbits seem have varied, as I will explain. On the whole, rabbits were usually somebody's property - for instance, the property of the owner of a 'big house,' its gardens, and its surrounding farmland, such as the property Peter Rabbit's family apparently lives on. What particular understanding was reached about rabbits caught or killed by a gardener in his area of responsibility, the gardens, at such a house may, however, have depended on what had been agreed between a Mr McGregor and his employer. Which implies that Potter's readers may have been uncertain whether Peter's father, who 'was put in a pie by Mrs. McGregor,' (Potter, Peter Rabbit 2002 p. 11) was a legitimate prey of the gardener, or an effective theft from the owner of the garden. Is
Mr McGregor, who chases Peter in that terrifying way, waving his rake and shouting 'Stop Thief' as if Peter were indeed a human, himself a thief with a furtively enjoyed rabbit pie on his conscience? The possibility intensifies the already-considerable narrative complexity and density of all four tales in the Peter Rabbit series.

Other Victorian sources - including fiction provide supportive evidence for my position and additional facts which throw light on contemporary ideas about rabbits as property, prey, and food. But the overall effect is to complicate rather than to clarify. In Anthony Trollope's An Eye for an Eye, (1879) for example, one of Trollope's little-known sensational stories, we see young Fred Neville being shown round the extensive estates he will one day inherit from the elderly Lord Scroope, a conservative, careful, prosperous landowner, by the earl's steward, who 'continued to instruct him during the whole ride.' Among other things, Fred learns that the 'farmers all shot the rabbits on their own land' (p. 61): as this is pointed out explicitly by the steward, it indicates that other arrangements were common, or, at least, possible. The other common arrangement, I assume, is that a landowner would reserve for self, family, and guests the privilege of shooting rabbits on the 'home' farm and other tenanted farms.

According to another very useful source of Victorian rural lore, Richard Jefferies' The Gamekeeper at Home, (1878) shooting rabbits was popular with 'young gentlemen' (36) which might indicate that Trollope's steward is warning Fred to expect no such frivolous pleasures on the well managed lands of his elderly relation. But what about rabbits despoiling the vegetable and flower gardens of a 'big house'? Were these generally understood, or explicitly conceded, to be a perk of the gardener's employment? Jefferies writes about southern England, not the north. ${ }^{9}$ But I have not so far found any evidence that in the north 
rabbits and rabbit shooting were not enjoyed as sport, rabbits were not regarded as property, and were not protected as such. Jefferies:

In the winter half a dozen young gentlemen have a turn at the ferreting; a great burrow is chosen, three or four ferrets put in at once without any nets, so that the rabbits may bolt freely, and then the shooting is like volleys of musketry fire. For sport like this the young gentlemen tip [the gamekeeper] freely.

(Jefferies 1978, pp.18-19).

Jefferies also describes a new social phenomenon. Shooting, it seems, is increasingly often being let or rented to social groups, a band of tradesmen from a neighbouring town, for instance (pp.36-7). Clearly rabbit shooting was a marketable commodity, for these deals generally involved 'partridges, haires, and rabbits' and Jefferies comments: 'Game, in short, was never so much sought after as at present' (p.37). The clients in such arrangements were presumably people rather like the Potters, well off, having money made in business or trade, and preferring to periodically enjoy the pleasures of rural landowning to actually being rural landowners.

There is also evidence in fiction that the various categories occupied by rabbits may have confused the Victorians themselves. Miss Phoebe, younger of the two Miss Brownings, a pair of impoverished ageing spinsters in Elizabeth Gaskell's Wives and Daughters, (1867) is certainly confused when she inadvertently reveals to $\mathrm{Mr}$ Osborne Hamley, son and heir of a local squire, that they have bought a couple of rabbits from the ostler at a nearby inn: 'I hope we shan't be taken up for poachers, Mr Osborne - snaring doesn't require a licence, I believe?' (Gaskell 1987, p.520). This is a joke, as it was not the snaring which mattered so much as the taking of rabbits on somebody else's land. A helpful footnote in the
Oxford World's Classics edition of Wives and Daughters refers Miss Phoebe's difficulties to the Game Act of 1831 ( $1 \& 2$ William IV, c. 32). This Act states that 'the taking and selling of game required a licence, but the Game Act of $1831 \ldots$ deemed game to be hares and a variety of birds; rabbits were not counted game' - a distinction I do not find easy to understand. Gaskell's Squire Hamley himself categorises rabbits in the same way as the Game Act. This elderly Wives and Daughters character represents an almost obsolete class of yeomen independent small English landowners and farmers - and he is uneducated, in many ways a primitive. Yet he is obsessively, and touchily, proud of his ancient lineage. Having had both his sons well educated at a public school (Rugby) followed by university (Cambridge) the Squire, with 'an exaggerated consciousness of the deficiencies of his own establishment as compared with what he imagined' (Gaskell 1987 p. 261) his sons' grander friends were used to at their own homes, has never encouraged his boys to invite their school friends to visit. He explains his reluctance in this way: 'You see, all you public schoolboys have a kind of freemasonry of your own, and outsiders are looked on by you much as I look on rabbits and all that isn't game. Ay, you may laugh, but it is so, and your friends will throw their eyes askance at me, and never think of my pedigree, which would beat theirs all to shivers, I'll be bound. No: I'll have no-one here at the Hall who will look down on a Hamley of Hamley...' (Gaskell 1987, p. 261).

By representing himself among his sons' fine friends as a rabbit among game, Hamley makes an analogy between social class and animal categories which harks back to medieval distinctions of rank, when different kinds of animals were assigned to each rank as worthy quarries. The Squire is here (once again) characterised as old-fashioned, out of step with the ways of 'young gentlemen' like those who enjoy shooting rabbits according to The Gamekeeper at Home. But despite rabbits 
falling outside the category of game - whatever that might mean - and despite what is clearly a general understanding, as it is shared by the law, Jefferies, and Squire Hamley, that the rabbit is 'of 'low degree' in comparison with the pheasant' (Jefferies 1978 p.79), I still feel fairly confident that taking a rabbit from somebody else's land was a crime. Jefferies clearly thinks so. He numbers among the useful occupations of the gamekeeper his keeping an eye on the potential dishonesty of such temporary employees as beaters, ferreters, ditchers, hedgers and such like: 'Without a doubt these men are very untrustworthy, and practise many tricks. For instance, when set to ferret a bank, what is to prevent them, if the coast is clear, from hiding half a dozen dead rabbits in a burrow? Digging has frequently to be resorted to, and thus they can easily cast earth over and conceal the entrance to a hole. Many a wounded hare and pheasant that falls into the hands of the beaters never makes its appearance at the table of the sportsman ...' (p.29) - indeed Jefferies is often made gloomy by widespread rural deceit and miscreancy. He has hard words to say about those who take rabbits from another's land, and he also, whatever the Act of 1831 might say, habitually refers to rabbits as game: 'For, since the price of rabbits has risen so high, they are very profitable as game, considering that a dozen or two may be captured without noise and ... perhaps in single hedge' (p.114). The profit referred to here came from meat, but rabbit skins and fur were also 'still bought in large quantities' (p.25).

Readers of Peter Rabbit perhaps hardly need to be reminded of that book's subtext, an underlying awareness that rabbits, bold raiders though they be, also commonly die violently, the prey of men or other animals. ${ }^{10}$ But Jefferies' words on the market value of rabbits are very relevant to $\mathrm{Mr}$ and Mrs McGregor's quarrel over the fate of the Flopsy Bunnies, Mrs McGregor wanting to use their skins to line her old cloak, Mr McGregor preferring to turn them into cash to buy tobacco. The baby rabbits are worth money, whether saved by Mrs, or gained by $\mathrm{Mr}$, McGregor. Jefferies also describes at some length the snaring or 'wiring' of rabbits as well as hares by poachers, (p.119) the use of ferrets by poachers, (pp.119-20) and 'the main difficulty with [poaching] any kind of game' which is that of getting 'home unobserved with the bag' (p.120) - a comment which throws light on the (literal) bags carried by many folktale ogres, also by $\mathrm{Mr}$ McGregor, in The Tale of the Flopsy Bunnies, and Tommy Brock, in The Tale of $\mathrm{Mr}$ Tod. Only after reading Jefferies did I examine the front cover of $\mathrm{Mr}$ Tod again, and realise that $\mathrm{Mr}$ Tod carries (what I assume to be) rabbit snares on his right foreleg, and has what could be the ears of young rabbits poking out of his bulging left pocket - I had previously taken these for the fingers of a glove. Perhaps $\mathrm{Mr}$ Tod's gentleman-farmer's dress suggests a kind of poacher whom Jefferies especially resents as very hard to identify, because his daily life is so apparently respectable.

Categorical confusion certainly seems to rule if rabbits were commonly named as both 'game' and 'vermin' (the latter, in the meaning of pests which endangered crops, might, I assume, be killed by anybody.) And a rabbit trespassing in your own garden could certainly be killed: Potter describes a 'hunt' for young rabbits among her cabbages in one of her letters (Lear 2007, p. 290). She also describes releasing a rabbit from a snare while on holiday. 'They are regular vermin, but one cannot stand to see a thing mauled about .... I fancy our actions were ... illegal' (Potter, in Hollindale, p.162). Potter's words here cover two contradictory categories to which rabbits belonged, vermin and game, the latter implying a form of private property. Similarly, to a child who had written to her, Potter replied in a 1917 letter: 'I have lots of rabbits, Belgians - Old Benjamin and Cottontail are pets, but I'm afraid we do have rabbit pies of the young ones' (in Lear 2007, p.292). Potter's apologetic tone indicates her 
awareness of the difficulties understanding the versatile rabbit could present to a child: in this case, by being both food and not-food, pet and not-pet.

I conclude that rabbits to Potter's contemporaries were conceptual, as well as physical, boundary breakers, a kind of crossover animal. Peter's squeezing 'under the gate' to get into Mr McGregor's garden (Potter, 2002, Peter Rabbit, p.20) and his later escapade in The Tale of Benjamin Bunny (1904) of falling out of a pear tree over the garden wall (Potter 2002, p.23) are cases of literal boundary-breaking which match up with and reinforce Peter's other category switches, such as his tendency to shed and reassume human clothing, and his overall human/animal hybridity, his ever wavering, infinitely reversible, textual/visual situation somewhere on the boundary which separates and joins animal and human. That Peter straddles this boundary is an effect often produced by Potter's illustrations of Peter's 'human' actions and poses such as those in Peter Rabbit on $\mathrm{p}$. 11 (Peter with hands in pockets) and p. 44 (Peter weeps as he stands forlornly against the locked garden door). It seems very probable that Peter's boundary crossings include passing from the category of property to not-property, and vice versa. Additionally, Potter's many possible late-Victorian ways of thinking about rabbits would include seeing them as symbols of unbridled fertility, as in the popular phrase 'to breed like rabbits.' In The Tale of Mr Tod (1912) Benjamin describes his stolen offspring as seven in number, 'and all of them twins!' (Potter 2002, p.22). Flopsy's litter of seven has, evidently, followed the earlier litter of six who were stolen by Mr McGregor in The Flopsy Bunnies (1909): the fertility of rabbits is certainly inscribed in the Peter Rabbit series for anybody who wishes to read it, as is their vulnerability to predators, with an implied acknowledgment that fertility is the key to rabbit survival.
To sum up the many rabbit-categories familiar to Potter, then, rabbits were prolifically breeding wild and domestic animals; they were food, providing both wild and farmed meat; they were a wild or farmed source of fur; they were pets; they were commonly the prey of other animals; they were pests or vermin; and they were also game, in the sense that they were property, and in the sense that killing rabbits provided both food and sport. Other factors would also have increased Potter's experience of the manifold and complicated ways rabbits related to humans. For instance, Potter almost certainly knew about rabbit coursing, a betting sport kept up by a combination of farmers and coal miners which involved setting two dogs into competition against each other to chase and kill a rabbit released from a bag. Coursing survived in northeast England for years beyond the turn of the century. Poaching, too, was a perpetual subject of rural gossip and debate. For example, Potter could hardly have avoided being aware of the controversy which accompanied the trial and hanging for murder of two men who killed two gamekeepers when in danger of being apprehended for poaching near Aldbury in Buckinghamshire in 1892.

Indirectly referencing such matters of public concern, Potter incorporates into her tales for children possibilities of death and violence while repeatedly positing the interchangeability of human and animal identity - two normally exclusive categories, which are repeatedly brought by Potter into playful relations through the mixed animal/human nature of her characters. In the Peter Rabbit series that we see elaborate games played out round the themes of category-switching and exchanges of identity. Thus Peter, if he is a boy or human being, is a 'thief', and rather like a poacher. $\mathrm{Mr}$ McGregor may also be a thief or poacher of rabbits like Peter. In Benjamin Bunny Mrs Rabbit keeps a shop, and the narrator claims to have been her customer. Benjamin Bunny and Peter are rescued and punished for their 
disobedience by Benjamin's father simultaneously an authoritative adult figure playing the familiar roles of ensuring the safety of, and chastising, two naughty children, and himself an outrageous sinner, a rabbit raider of gardens. And yet, after all, within a third category, at bottom old Mr Benjamin Bunny is only an animal, whose innocent rabbit nature it is to take his natural food where it is to be found. The Flopsy Bunnies, with its elaborate and beautiful garden scenes and its interest in boundaries, in walls and fences and bags which exclude and confine and hide, introduces further levels of ambiguity and human/animal interchange into the series. The baby rabbit victims are caught outside the garden wall, which may imply they are not really $\mathrm{Mr}$ McGregor's responsibility, or perquisite, at all. The Flopsy family is assisted by a traditional figure, that of an apparently small and powerless 'animal helper', a grateful mouse like the one who frees the lion in Aesop's fable. She later becomes the heroine of another Potter tale. In innumerable images and their accompanying narrative developments in this series slippages from one category to another occur, such as in the sequences featuring cats, which are animals without clothing or speech, (ambiguously) pets of humans as well as predators of small rabbits. As Benjamin Bunny shows us, a cat may easily be transformed into a defeated victim by a fearless adult rabbit. In $M r$ Tod, notoriously, Potter's written text refers to her two main characters as 'people' (7) and does not begin to be explicit about their identities as 'fox' and 'badger' until pp. 40 and 43. Particularly in the extended form of the Peter Rabbit four-book series, I would argue, Potter is everywhere assisted in focusing on her unnerving temporary suspensions or abrogations of familiar and fundamental category and identity differences by the mobility and versatility of boundarycrossing rabbits - qualities then further extended by her own peculiar gift of ironic fantasy. Her leaps of imagination are exemplified particularly memorably when in Peter's adult career, in The Flopsy Bunnies, as a 'nursery gardener' or self-employed $\mathrm{Mr}$ McGregor he may be seen to have erected rabbit-proof fences around his own garden (Flopsy Bunnies, pp.12-13).

The Peter Rabbit series I am describing here provides plenty of fun for adult readers. What of the child reader? I suggest that Potter's elaborate games of mobility and interchange replicate, and acknowledge with sympathy, common childhood experiences: the experience of rapid passage from one kind of category to another - old enough to do this, but not old enough to do that, socially welcome at one moment, banished to the nursery at the next moment - but also the common childhood experiences of getting it wrong, of misrecognition, or miscategorisation, of oneself and others, of often taking part in games, rituals, social occasions and institutions only dimly understood and offering many difficulties of negotiation and acceptability. The Rabbit family's talk, and the Peter Rabbit series narrator's talk, which repeats that of the family, about 'Mr McGregor's garden,' is a joke which touches on the familiar figure of the Scotch gardener. But it also betrays a social error of misrecognition by the child Rabbits. Of the social class of respectable village folk or cottagers - local agricultural labourers, village artisans, small shopkeepers, odd jobs men and women, servants - a Rabbit family might see, know, possibly work for, a Mr McGregor, but would generally have little to do with the real owners of 'his' garden. The Rabbit children, if tempted to help themselves to produce from a Mr McGregor's garden, would therefore inevitably think of it as the domain of the gardener, its active defender, and so this is how the family refers to it. I assume that this Potteresque joke would have been well within the grasp of class conscious and socially welltrained children, such as Potter's own wealthy family produced. Peter, after he has undertaken an expedition which we feel to be dangerous but somehow admirable, an attempt to match himself against his missing father - perhaps to 
replace him - in glorious thievery of food, is speedily reduced by his own helpless terror from somewhat more than boy to somewhat less than $\mathrm{r} /$ Rabbit. Children are very familiar with such sudden emotional descents, such reductions of the self.

At times, reading Potter can produce a sense of vertiginous descent. Mr Tod, in the frontispiece to his own book, is seen to keep a sporting print of a fox hunt on his wall. Peter grows up into the sort of adult who fences out rabbits. Such details, where the animals themselves apparently share humans' conceptual problems over the proper categorisation of animals, are, I assume, readable only by older children and adults, who seem more likely than child readers to ponder social analogies to the ways Potter's animal characters can apparently misrecognise their own identity. And along with animals' own miscategorisations, other disconcerting miscalculations and slippages from one category to another abound in this series. Related themes are further developed in Benjamin Bunny when Peter accompanies his cousin Benjamin back to $\mathrm{Mr}$ McGregor's garden to retrieve his own clothing from the scarecrow. At that time, Benjamin tries on $\mathrm{Mr}$ McGregor's old tam-o'shanter (Benjamin Bunny, pp.26-7), a scene which has been dismissed as evidence of the deterioration of Potter's narrative, in this sequel, towards the merely picturesque and sentimental. But Benjamin's temporary assumption of a rafish Scottish adult persona is an interesting act, in the light of my argument that $\mathrm{Mr}$ McGregor may himself be dishonest. Benjamin is after all a 'professional' rabbit/robber, an unashamed raider of the garden, used to making regular trips with his father to get lettuces for the family's Sunday dinner. Perhaps, in sharing $\mathrm{Mr}$ McGregor's hat, he also shares an aspect of his identity. I suspect that tam-o-shanter had a Rob Roy-ish or disreputable, freebooting air to contemporary readers - and it's difficult to know what other aspect of $\mathrm{Mr}$ McGregor Benjamin might be assuming along with his hat, as Benjamin certainly is no gardener. But, another sudden descent, a reduction of Benjamin's glory to helpless immobility, quickly follows, as he and Peter must hide from the cat under a basket. The intervention of old Mr Benjamin Bunny, whose elevated position atop the wall, upright (almost military) posture, royal-purple coat, and plentiful phallic appendages, (tail, pipe, switch) signal his somewhat more than adult and fatherly status then results in another exchange of roles, categories, and places: the cat is put into confinement, and the robber-rabbits Benjamin and Peter reduced to snivelling infants, as Peter's substitute father figure asserts his proper place and relieves Peter from the responsibility, and dangers, of trying to take, too early, his own dead father's place.

Fluidity and interchange of identity is further developed via Potter's scarecrow, which functions as a connector between the earlier Peter Rabbit and later Benjamin Bunny, and which also merits interrogation in connection with the possibility that Mr McGregor himself occupies the category of thief. That scarecrow was last seen in a memorable illustration towards the end of The Tale of Peter Rabbit: an illustration which seems, with the vertiginous effect mentioned above, to drop us into an abyss of infinitely receding instances of human/animal identity and difference shuffled, imbricated, suggestively interchanged. The scarecrow may be read as an emptied out Peter, a mere simulacrum of Peter, reduced to only his clothing hanging on a stick - which perhaps acknowledges that a clothed Peter Rabbit has all along been no more than Potter's fantasy construct. In that scarecrow, however, $\mathrm{Mr}$ McGregor also reproduces himself, the garden's guardian, as demonstrated by his giving it his own hat. A scarecrow is a human effigy, after all, and Peter Rabbit's clothes did not frighten the birds (as we can see from the 
Peter Rabbit picture on p. 52). The scarecrow thereby comes to represent another site of the interchange of human and animal, or of robber and rabbit, identity.

The custom of stringing or hanging up the remains of farm pests such as crows, or nailing the bodies of dead pests to the end wall of a barn, whether as a grim warning to other pests, in triumph, or as a kind of magical prophylactic, is also recalled in the combined trophy and warning which is Mr McGregor's scarecrow. The scarecrow therefore also stands for Peter's threatened fate: it is a gibbet, the promise of his death. Peter's continuing danger is after all also represented in this Peter Rabbit picture by $\mathrm{Mr}$ McGregor, labouring in the background of p. 52 as he continues to bring forth from his garden food well guarded against all animal enemies.

Potter returned to this rich image in two further scarecrow pictures in Benjamin Bunny. I want to use the second of these, which is our last glimpse of the garden and the penultimate picture in that book, to complete my essay and recall the theme with which I opened it, the injustice done to Beatrix Potter when critics' anxiety to do justice to her realism stands in the way of what should be an equally enthusiastic acknowledgement of the subtlety and power of her fantasy constructions.

For the final scarecrow picture (Benjamin Bunny, pp.54-5) is a fine example of Potter's peculiar subtleties as fantasist in words and pictures. In it Mr McGregor, himself wearing what appears to be a new tam o'shanter, stands lost in contemplation of his own scarecrow which, stripped of Peter's coat and shoes by Benjamin and Peter, is now hardly more than a mere upright stick, though still topped by $\mathrm{Mr}$ McGregor's own old tam. Mr McGregor's multiple mental confusions are strongly represented here. He is mystified by the cat's having managed to lock itself into a greenhouse from the outside, and by the tiny traces, footprints made by a 'ridiculously little' pair of clogs, in his own garden, as well as, we assume, by the disappearance of Peter's coat and shoes. In another experience of a sudden reduction of identity, Mr McGregor may be contemplating his own despoiled and mocked at self. This double page spread therefore works like a game, a tease, or joke played on the reader, by Potter. Mr McGregor's bemusement suggests his (our?) state of mind, caught in a moment where fictional 'reality' and Potter's fantasy achieve a well-managed collision, and unanswerable questions (such as 'but surely rabbits can't lock doors any more than cats can?') occur to the mind only to be abandoned with a smile. The picture ultimately defeats any stable reading - but remains productive of meanings nevertheless. In it we see, firstly, the many ambiguities of the theme of the robber robbed. Mr McGregor is a food producer of subordinate status whose produce really belongs to somebody richer and more powerful then he. As himself a depredator and predator, even if only in a small way, though, $\mathrm{Mr}$ McGregor stands lost in contemplation (admiration?) of the audacity of other even smaller thieves, whom he would like to eat, but who turn the tables on him by repeatedly eating up his substance, his source of livelihood.

Secondly, Mr McGregor's companion, the cat, repeats similar themes: the cat is a servant, a pest-controller, a dependent, and a subordinate, but is also another predator, an animal with an interest in eating up small rabbits which has been thwarted in that natural aim by the rabbits themselves. Thirdly, all this continuing evidence recalls Peter's and Benjamin's partial success as raiders, for they did triumph over $\mathrm{Mr}$ McGregor by recovering Peter's clothing, as well as - with parental assistance - taking food from the garden and escaping (and imprisoning) the cat. Finally, from the top of the garden's boundary wall, a boundary which tries to lock away from rabbits their natural sustenance, rabbit robbers line up to enjoy, with human emotions, the discomfiting of their enemy: and to watch, like animals, for an opportunity to 
revisit the garden once again. The lesson of the picture might be that humanity's boundaries and borders, its locked doors and walls whether categorical or literal, are quite inadequate to enclose or encompass the complexity of the mobile, and mutually exchangeable, relations of human and animal nature, of robber and rabbit perhaps even, as my essay title suggests, of the complex interchangeabilities of Peters and Potters. The pleasure of tracing a complex of human/animal interchangeabilities through multiple categories into which both fit is a gift made to us by Potter's exploratory fantasies in all four small books of the Peter Rabbit series.

\section{NOTES}

1. For another example from Lane's biography, see the caption to the colour plate from The Roly-Poly Pudding reproduced in The Tale of Beatrix Potter, which reads: ' 'Tom Kitten got upon the fender and looked up.' The Kitchen range at Hill Top Farm.' (Facing p. 129). For further examples of this tendency, see the works listed in Note 2.

2. See Golden; Linder; Hobbs \& Whalley; Lane; Taylor, and Taylor, Whalley, Hobbs and Battrick. Taylor et al largely focus on the transition from Potter's art based in real-world observation to its re-creation in illustrations for her fictions. Battrick comments: 'She copied the way of life she gave her animals from what she saw around her. ... The books and the life and landscape of the Lake District merged together. ... Beatrix was part of a trend towards realism what she called 'copying what she saw'. She painted the countryside exactly as she saw it' (Battrick 1987, p. 178).

3. Lear comments in Beatrix Potter: A Life in Nature that in spring 1912 Potter, working on the illustrations for Mr Tod, 'still had to correct some of the fox's anatomy and so spent time in the Natural History Museum looking at photographs and reference books' (Lear 2007, p.245).
4. See also Peter Hollindale's 'Humans are so Rabbit', where the subversive Peter's reduction to a 'highly respectable citizen' (Hollindale 2002 , p. 170) is made to equate to his becoming progressively more human and less rabbit-like in behaviour. To Hollindale, the more rabbitlike Peter is, the more realistic he is, and the more subversive he is (see p. 163).

5. On the other hand, Goldthwaite falls into a familiar pattern when he remarks that the 'Potter ... who counts in the end, is that stoical naturalist' (291). He is also eloquent on - and hostile to - Potter's 'prettiness' (p. 289), her 'whimsy', her 'retreat to the nursery', her 'preciousness', and 'quaintness' and her capacity for 'skewing whole books towards the sentimental' (p.290).

6. We hear about the further fate of this gardener, who made 'a pretty good livelihood by the garden, which he farmed, and of which he sold the produce at Southampton,' in Chapter 39, where Thackeray characterises him 'and his Scotch wife, and Scotch children' as 'the only respectable inhabitants' remaining at Queen's Crawley in Sir Pitt's decline. They are nevertheless 'forced to migrate' after getting on the wrong side of Sir Pitt's mistress (Thackeray, (1983) Vanity Fair, p. 502).

7. Stevenson's essay was written during his university days and had earlier appeared in the Edinburgh University Magazine 3, pp. 71-6, in March 1871, (see Prideaux, 1917 p.182). It was 'retouched in after days' (Balfour 1901 p.103) for inclusion in Memories and Portraits. The character of the Scots gardener lives on, of course, in Groundskeeper Willie in the television animated comedy series The Simpsons, where he maintains the traditional characteristics of claiming, and exercising, freedom of action and controlling his own employers.

8. Stevenson's Scotch gardener is called Robert: probably not a coincidence. 
9. Jefferies' 'gamekeeper' character is a typical rather than a biographical or individual figure. He seems to be located somewhere around where Swindon is now.

10. Davis and Demello (2003) claim that: 'life is a risky business for most wild rabbits. Mortality rates for warrens can reach as much as ninety percent annually [and] wild European rabbits between the ages of four and eight months have only about a fifty percent chance of surviving at all' (p.13).

\section{REFERENCES}

Balfour, Graham (1901) The Life of Robert Louis Stevenson, $2^{\text {nd }}$ ed. London, Methuen.

Cummins, June (2002) "You should not loiter longer": Beatrix Potter, Christina Rossetti, and progressive intertextual revision", in Margaret Mackey (ed) Beatrix Potter's Peter Rabbit: A Children's Classic at 100. Lanham, MD., Scarecrow Press, pp. 79-98.

Davis, Susan E. \& Margo Demello (2003) Stories Rabbits Tell: A Natural and Cultural History of a Misunderstood Creature. New York, Lantern Books.

Gaskell, Elizabeth (1987) Wives and Daughters (1867). Ed. Angus Easson. Oxford, Oxford UP.

Golden, Catherine (1994) "Beatrix Potter: Naturalist artist", in Bill Katz (ed) A History of British Book Illustration: 29 Points of View. The History of the Book 1. Metuchen, N.J.; London, Scarecrow Press, pp. 626-641.

Goldthwaite, John (1996) The Natural History of Make-Believe: A Guide to the Principal Works of Britain, Europe and America. New York, Oxford UP.
Greene, Graham (1969) "Beatrix Potter", in Sheila A. Egoff, G.T. Stubbs, L.F. Ashley (eds) Only Connect: Readings on Children's Literature. New York, Oxford UP, pp. 29198.

Harris, Joel Chandler (1955) The Complete Tales of Uncle Remus. Boston, Houghton Mifflin.

Hobbs, Anne Stevenson \& Joyce Irene Whalley (1985) Beatrix Potter: The $V \&$ A Collection: The Leslie Linder Bequest of Beatrix Potter Material. London: Victorian and Albert Museum/Frederick Warne.

Hollindale, Peter (2002) "Humans are so Rabbit", in Margaret Mackey (ed) Beatrix Potter's Peter Rabbit: A Children's Classic at 100. Lanham, MD., Scarecrow Press, pp. 161-172.

Jefferies, R. (1978) The Gamekeeper at Home; The Amateur Poacher (1878 and 1879). Oxford: Oxford UP.

Lane, Margaret (1962) The Tale of Beatrix Potter (1946). Harmondsworth: Penguin.

Lane, Margaret (1978) The Magic Years of Beatrix Potter. London; New York, Frederick Warne.

Lear, Linda (2007) Beatrix Potter: A Life in Nature. New York, St Martin's Press.

Linder, Leslie (1971) A History of the Writings of Beatrix Potter: Including Unpublished Work. London; New York, Frederick Warne.

Linder, Leslie and Enid (1972) The Art of Beatrix Potter. Rev.ed. London; New York, Frederick Warne.

Mackey, Margaret (ed) (2002) Beatrix Potter's Peter Rabbit: A Children's Classic at 100. Lanham, MD., Scarecrow Press. 
Noonan, Chris (dir) (2006) Miss Potter.

Weinstein Company.

Paul, Lissa (2002) "Beatrix Potter and John Everett Millais: Reproductive technologies and coolhunting", in Margaret Mackey (ed) Beatrix Potter's Peter Rabbit: A Children's Classic at 100. Lanham, MD., Scarecrow Press, pp. 53-75.

Pollard, Scott \& Kara Keeling (2002) "In Search of his father's garden", in Margaret Mackey (ed) Beatrix Potter's Peter Rabbit: A Children's Classic at 100. Lanham, MD., Scarecrow Press, pp. 117-130.

Potter, Beatrix (1987) The Tale of Peter Rabbit (1902). London: Frederick Warne.

Potter, Beatrix (2002) The Tailor of Gloucester (1903). London: Frederick Warne/Penguin

Potter, Beatrix (2002) The Tale of Benjamin Bunny (1904). London: Frederick

Warne/Penguin.

Potter, Beatrix (2002) The Tale of the Flopsy Bunnies (1909). London: Frederick Warne/Penguin.

Potter, Beatrix (2002) The Tale of Mr Tod (1912). London: Frederick Warne/Penguin.

Prideaux, William Francis (1917) A Bibliography of the Works of Robert Louis Stevenson. London, F. Hollings.

Scott, Sir Walter (1998) Rob Roy (1817), ed. Ian Duncan. Oxford; New York, Oxford UP.

Stevenson, Robert Louis n.d. "An Old Scotch Gardener" (1887), in Memories and Portraits http://www.fullbooks.com/Memories-andPortraits1.html. London, Chatto and Windus edition (1912). Scanned and proofed by David Price. Accessed 19/5/09.

Taylor, Judy (1986) Beatrix Potter: Artist, Storyteller and Countrywoman. London, Frederick Warne.

Taylor, Judy, Joyce Irene Whalley, Anne Stevenson Hobbs, \& Elizabeth M. Battrick (1987) Beatrix Potter: The Artist and her World. London, Frederick Warne/National Trust/Penguin.

Thackeray, William Makepeace (1983) Vanity Fair (1847-8). Ed. John Sutherland. Oxford: Oxford UP.

Trollope, A (date unk.) An Eye for an Eye. Place of publication unk., Hard Press.

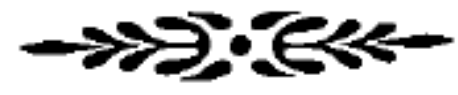

\section{BIOGRAPHICAL NOTE}

Rose Lovell-Smith is a Senior Lecturer in the English Department, University of Auckland, where she convenes a course called Children's Literature: Words and Pictures. Her teaching and research interests include nineteenthcentury fiction, feminist writing and women's fiction, oral literature and the fairy tale, and women's rewriting of fairy tales. She is currently working on a historical study of the illustrated book for older children, which will contain a chapter on Beatrix Potter's Peter Rabbit Series, and has published recently on the natural history contexts of both words and pictures in Lewis Carroll's Alice books. 